\title{
IMPLEMENTASI PERAN PEREMPUAN DALAM PELAYANAN GEREJA
}

\author{
Oleh: Agustina Ruru
}

\begin{abstract}
Abstrak
Gereja adalah milik Kristus dan berada di dunia ini untuk melakukan tugas yang diberikan Kristus kepadanya sesuai dengan Amanat Agung dari Yesus Kristus (Mat.28:19- 20), maka salah satu tugas penting gereja adalah melayani. Melayani dapat berarti mengosongkan diri dan menempatkan kepentingan sendiri di bawah kepentingan Tuhan dan kepentingan orang lain. Allah memanggil semua orang percaya untuk melayani dunia dan gereja, bukan melayani diri sendiri. Gereja-gereja dipanggil untuk menguji kembali struktur gereja dan mengusahakan keseimbangan arti memberi peranan penuh dari seluruh anggotanya tanpa terkecuali baik lakilaki maupun perempuan sama-sama mendapat peran yang seimbang dalam gereja, sehingga mereka benar-benar dapat berperan sesuai dengan bakat dan talentanya masing-masing.
\end{abstract}

\section{Pendahuluan}

Yesus Kristus telah mempercayakan tugas yang mulia kepada umat-Nya. Setiap orang percaya diciptakan untuk melayani (Ef. 2:10) dan diperintahkan untuk melayani (Mat. 20:26-28) sehingga kaum awam merupakan kunci keberhasilan suatu pelayanan dan peranan kaum wanita dalam gereja sangatlah penting. Rick Warren mengatakan, "Tidak ada satu pelayanan yang mampu berdiri sendiri. Karena tidak ada pelayanan yang dapat melaksanakan segala sesuatu yang harus dilakukan oleh gereja, kita harus bergantung pada dan bekerjasama satu sama lain.

Dalam persekutuan yang merupakan dambaan adalah pelayanan dapat berjalan dengan baik dan lancar. Karena apabila pelayanan berjalan dengan lancar, maka apa yang menjadi tujuan dari persekutuan dapat tercapai. Pelayanan dapat maju apabila setiap anggota-anggotanya turut terlibat dalam pelayanan. Untuk itu kaum wanita memegang peranan penting dalam mendukung kelancaran pelayanan dan kaum wanita dapat berperan jika mereka dibina dan diarahkan untuk memahami tanggung jawab mereka. 


\section{Tujuan dan Manfaat}

Agar mengetahui peran perempuan di dalam suatu gereja atau jemaat agar dimana para pemudi saat ini juga dapat mengambil bagian dalam gereja dan mengambil satu tanggung jawab di dalamnya.

\section{Pembahasan}

Peranan berasal dari kata dasar peran yang berarti, Sesuatu yang diharapkan dimiliki oleh orang yang memiliki kedudukan dalam masyarakat. Sedangkan peranan berarti Bagian yang dimainkan oleh seorang pemain atau tindakan yang dilakukan seseorang dalam suatu peristiwa. Sehingga peranan merupakan suatu bagian atau tugas utama yang dimainkan atau dilakukan oleh seseorang. Untuk kata wanita dalam Kamus artinya perempuan dewasa. Simon Runtung mengatakan, "Orang dewasa adalah orang yang berumur 25-65 tahun yang memiliki kematangan mental dan spiritual. Jadi dapat disimpulkan bahwa kaum wanita adalah orang yang telah dewasa baik secara mental maupun spiritual.

Dengan demikian, peningkatan peranan kaum wanita adalah proses atau usaha untuk meningkatkan suatu kegiatan yang merupakan tugas utama yang dilakukan oleh kaum wanita. Peningkatan peranan kaum wanita penting untuk dilakukan dengan jalan kaum wanita perlu dibimbing dan diarahkan menjadi suatu pribadi yang bertanggung jawab kepada Tuhan, dengan berbagai usaha atau kegiatan yang berdaya guna terhadap seluruh kaum wanita untuk dapat mengembangkan dirinya dalam pelayanan kepada Tuhan. Bestiana Simanjuntak mengatakan, Gereja bertugas melatih dan melibatkan setiap anggotanya dalam pelayanan yang aktif, baik di dalam lingkungan gereja maupun keluar. Untuk itu gereja membuka kesempatan bagi kaum wanita untuk menjalankan peranan mereka, melalui program-program yang telah disepakati bersama.

Pelayanan dari kata Latin, ministerium yaitu peranan yang diterima melalui pertunjukan resmi dan yang diwujudkan dengan wibawa dengan kata ini disebut pula berbagai jenis kuasa sipil, pelayanan liturgis Yahudi, status Yesus Kristus sebagai Imam, juga wibawa-Nya yang akhirnya beberapa fungsi yang dipercayakan kepada umat beriman. Kemudian kata-kata Yunani yang utama berkaitan dengan pelayanan Kristen ialah dari diakonia pelayanan, exousia yaitu wibawa, kuasa, oikonomia yaitu tata usaha, kharis/kharisma yaitu pemberian cuma-cuma. 
Dalam Perjanjian Lama, nampak mengenai para wanita-wanita yang dipilih dan dipakai oleh Allah untuk menyatakan kuasa dan kehendak-Nya bagi dunia ini. Allah tidak memandang rendah kaum wanita sebagai kaum yang lemah tetapi justru Allah menciptakan manusia untuk bersama-sama dengan kaum laki-laki melaksanakan amanat Tuhan di dunia ini (Kej. 2:8-25).

Sekalipun pada dasarnya wanita sama derajatnya dengan laki-laki, tetapi karena akibat dosa yang dilakukan perasamaan itu telah berubah sebagaimana Tuhan katakan kepada wanita, laki-laki akan berkuasa atasmu (Kej. 3:16). Namun, hal ini bukan berarti kaum wanita sama sekali tidak bernilai, tetapi hanya ada perubahan kedudukan antara lakilaki dan perempuan. Oleh sebab itu mereka harus bersama-sama memenuhi tanggung jawab terhadap Allah sebagai pencipta mereka (Kej. 2:18).

Namun pada kenyataannya dalam Perjanjian Lama ada juga kaum wanita yang mempunyai potensi besar sekalipun dalam konteks Yahudi wanita dipandang lebih rendah derajatnya. Wanita yang dipakai oleh Tuhan untuk menolong orang lain secara khusus hamba Tuhan di antaranya adalah seorang perempuan Sunem (II Raj. 4:8-22, 32-37). Ia dipakai oleh Allah untuk menolong nabi Eliza dengan memberikan tumpangan dengan pelayanan yang terbaik. Gien Karssen mengatakan, "Perempuan Sunem ini mempunyai perhatian yang besar terhadap dunia di sekitarnya. Ia memikirkan orang lain terlebih dahulu, bukan dirinya sendiri. Kepedulian yang besar terhadap orang lain merupakan salah satu bukti tanggung jawab dalam pelayanan. Perempuan ini tidak harus berkhotbah menyampaikan Firman Tuhan tetapi dengan kemampuannya dan melalui kesaksian hidupnya ia telah melayani Allah.

Dalam Perjanjian Baru juga dikisahkan tentang wanita yang melayani Tuhan Yesus. Mereka melayani Dia, baik dalam perjalanan-perjalanan-Nya (Luk 8: 2; Mark. 15: 40-41), maupun di rumah (Luk. 10: 38-42). Dalam Kisah Para Rasul 1:14 dijelaskan bahwa kaum wanita berkumpul bersama-sama dengan orang-orang lain pada hari Pentakosta dan mereka juga dipenuhi oleh Roh Kudus. Ini berarti bahwa mereka tidak tinggal diam ketika ada persekutuan tetapi mereka juga aktif turut mengambil bagian dalam pelayanan bersama dengan orang-orang percaya lainnya. 
Selanjutnya dalam Kis. 16:11-15,40 ada Lidia seorang wanita yang berprofesi sebagai penjual kain ungu dari kota Tiatira. Di tengah-tengah kesibukannya sebagai seorang pedagang, ia masih bisa meluangkan waktunya untuk Tuhan. Ia berkomitmen untuk setia kepada Tuhan dan menyatakan tanggung jawabnya melayani Tuhan dengan bersaksi kepada orang lain sehingga ia dapat membawa mereka kepada Tuhan. Gien Karssen mengatakan, Bagi Lidia, menjadi orang Kristen merupakan hal yang praktis. Ia tidak menjadi seorang biarawati, ataupun seorang penginjil sepenuh waktu. Ia tetap mengerjakan usahanya. Ia memperoleh nama yang baik dengan menyerahkan dirinya, usahanya dan harta miliknya bagi pelayanan yang semaksimal mungkin bagi Kristus. Meskipun Lidia tidak memegang jabatan sebagai seorang gembala tetapi Lidia memanfaatkan apa yang ia miliki untuk menyokong pelayanan Tuhan.

Kaum wanita merupakan bagian dari persekutuan jemaat yang patut mengambil bagian atau peranan penting bagi pengembangan pelayanan. Untuk itu kaum wanita memegang peranan sebagai motivator bagi sesama anggota jemaat untuk melayani sesuai dengan potensi dan kemampuan yang dimiliki.

Sebagai motivator, Tuhan menginginkan setiap kaum wanita dapat berdaya guna dalam pelayanan. Bukan hanya kaum pria yang dapat menjadi motivator tetapi juga bagi kaum wanita melalui tindakannya menjadi teladan sehingga mampu mempengaruhi orang lain dan tentunya motivasi yang dimiliki bertujuan untuk kemuliaan Allah seperti yang dikemukakan oleh Jeff Hammond, Kehidupan dan pelayanan yang berdasarkan fondasi lain daripada memuaskan hati Allah adalah sama seperti membangun dengan bahan-bahan yang mudah terbakar, motivasi sejati adalah menyenangkan hati Allah dan dari dasar itu Allah akan memberikan kita keinginan hati kita.

Sebagai orang percaya yang dipakai oleh Allah maka kaum wanita dituntut untuk menjadi teladan. Menurut Kamus kata teladan artinya dapat ditiru, menjadi panutan. Rasul Paulus menganjurkan bagi setiap orang percaya untuk menjadi teladan dalam segala hal. Karena Paulus sendiri telah menjadi teladan bagi orang percaya. Dalam II Tesalonika 3: 9 karena kami mau menjadikan diri kami teladan bagi kamu, supaya kamu ikuti. Selanjutnya dalam Titus 2: 7 Firman Tuhan mengatakan, dan jadikanlah dirimu sendiri suatu teladan dalam berbuat baik. Werren W. Wiersbe mengatakan,'Teladan itu meliputi perbuatan baik, ajaran yang sehat, sikap. 
yang sungguh-sungguh dan percakapan yang sehat ssehingga tidak seorang pun bahkan musuh sekalipun dapat menuduh.

\section{Kesimpulan}

Gereja dipanggil untuk melakukan tugas yang dipercayakan Kristus kepadanya, sesuai yang dinyatakan dalam amanat agung-Nya (Mat.28:19-20). Salah satu tugas penting itu adalah melakukan pelayanan. Karena pelayanan ini ditujukan kepada Gereja, hal ini berarti bahwa semua dituntut melayani tanpa terkecuali kaum wanita. Untuk itu kaum wanita juga memegang peranan penting dalam mendukung kelancaran dan kemajuan pelayanan .

Alkitab merupakan dasar untuk melaksanakan berbagai pelayanan dan yang menekankan bahwa setiap orang percaya harus turut terlibat dalam pelayanan. Mengenai pelayanan kaum wanita dalam Perjanjian Lama maupun Perjanjian Baru nampak mengenai para wanita yang dipilih oleh Allah sendiri dan dipakai untuk menyatakan kuasa dan kehendak-Nya bagi dunia ini. Allah tidak pernah memandang rendah kaum wanita tetapi justru Allah menciptakannya bersama-sama dengan kaum laki-laki melaksanakan amanat Tuhan di dunia ini.

Peranan kaum wanita dalam pelayanan akan sangat besar apabila bisa diberdayakan dan dioptimalkan dengan baik. Mereka dapat berperan aktif sebagai pelayan liturgis, pendoa, pelayanan perkunjungan dan pelayanan lain yang bisa berdampak pada kemajuan pelayanan dan pertumbuhan gereja. Akan tetapi ada faktor-faktor tertentu yang dapat mengakibatkan terhambatnya palayanan kaum wanita apabila tidak mendapat solusi yang tepat seperti kesibukan rumah tangga, kurangnya pembinaan dan pengaruh lingkungan. 


\section{Daftar Pustaka}

Borrowdale,Anne Tugas Rangkap Wanita. Jakarta: BPK Gunung Mulia, 1997.

Ismail,Andar Selamat Melayani Tuhan. Jakarta: BPK Gunung Mulia, 2004.

Darmaputera,Evang Wanita dan Berbagai Segi Kehidupannya. Jakarta: BPK Gunung Mulia, 1997.

Karssen, Gien Ia Dinamai Perempuan. Bandung: Kalam Hidup, 1974.

Retnowati, Perempuan-Perempuan Dalam Alkitab. Jakarta: BPK Gunung Mulia, 2004. 